Tropical Journal of Pharmaceutical Research July 2019; 18 (7): 1375-1384

ISSN: $1596-5996$ (print); 1596-9827 (electronic)

(C) Pharmacotherapy Group, Faculty of Pharmacy, University of Benin, Benin City, 300001 Nigeria.

\title{
Effect of pectin on properties of potato starch after dry heat treatment
}

\author{
Tian Jia, Jie Zeng*, Haiyan Gao, Jikai Jiang, Jingxiang Zhao, Tongchao Su, \\ Junliang Sun \\ School of Food Science, Henan Institute of Science and Technology, Xinxiang, 453003, China
}

*For correspondence: Email: zengjie623@163.com; Tel: +86-15836058250

Sent for review: 11 December 2018

Revised accepted: 16 June 2019

\begin{abstract}
Purpose: To evaluate the effect of pectin on the properties of potato starch after dry heat treatment. Methods: Rapid visco analyzer (RVA), differential scanning calorimetry (DSC), texture profile analyzer (TPA), scanning electron microscopy (SEM), Fourier transform infrared spectroscopy (FTIR) and x-ray diffractometry (XRD) were used to determine the properties of modified potato starch and pectin blends after dry heat treatment.

Results: Results from RVA showed that the peak viscosity of modified potato starch decreased gradually with increase in pectin concentration, dry heat time and dry heat temperature, while starch breakdown decreased and setback was increased to varying degrees. The lowest breakdown was 792 $c P$ at dry heat temperature of $140{ }^{\circ} \mathrm{C}$. Modified potato starch had broader ranges of gelatinization temperatures and lower gelatinization enthalpy than raw potato starch. Dry heat treatment improved the hardness, gumminess and chewiness of the gels of modified potato starch and pectin blends SEM micrographs showed some cluster shapes in microstructure after dry heat treatment of starch-pectin blends. Infrared spectra revealed that pectin addition and dry heat treatment did not cause changes in starch structure. However, $x$-ray diffractograms indicated that dry heat treatment weakened the third peak of potato starch.

Conclusion: These results indicate that dry heat treatment effectively alters the properties of potato starch and pectin blends. This finding broadens the applications of modified potato starch in food and pharmaceutical industries.
\end{abstract}

Keywords: Potato starch, Pectin, Dry heat treatment, Modification, Microstructure, Viscosity, Excipients

This is an Open Access article that uses a fund-ing model which does not charge readers or their institutions for access and distributed under the terms of the Creative Commons Attribution License (http://creativecommons.org/licenses/by/4.0) and the Budapest Open Access Initiative (http://www.budapestopenaccessinitiative.org/read), which permit unrestricted use, distribution, and reproduction in any medium, provided the original work is properly credited.

Tropical Journal of Pharmaceutical Research is indexed by Science Citation Index (SciSearch), Scopus, International Pharmaceutical Abstract, Chemical Abstracts, Embase, Index Copernicus, EBSCO, African Index Medicus, JournalSeek, Journal Citation Reports/Science Edition, Directory of Open Access Journals (DOAJ), African Journal Online, Bioline International, Open-J-Gate and Pharmacy Abstracts

\section{INTRODUCTION}

Potato starch is widely used in textile, aquaculture, pharmaceutical and food industries as commercial starch [1,2]. It is famous for its unique functional properties such as low gelatinization temperature, large particle size, high paste viscosity, and paste translucency [3]. However, potato starch is not very suitable for application in food processing because of its weak heat and shear resistance. Currently, starch modification is seen as an approach for improving the heat resistance, shear strength, and stability of starch [4-7]. 
The methods used for modification of starch are mainly chemical and physical methods. Chemical modifications require a variety of chemical reagents and complex processes, and produce many by-products [8-11]. Dry heat treatment is a novel physical method for preparing modified starch. It has the advantage of simple operation, high security, and absence of pollution [12].

A study has compared the relationship between starch digestibility and physical properties of high amylose starches and their characteristics by principal component analysis (PCA) [13]. The results showed that heating temperature was negatively correlated with starch digestibility, paste viscosity, and gel strength. Blending of starch and edible gum is often used to improve the quality and stability of foods [14-16]. Ionic glue is usually used to improve the physical properties of starch under dry heat treatment. lonic glues such as xanthan gum, sodium alginate and sodium carboxymethyl cellulose (CMC) have been used to prepare modified starch with dry heat treatment [17-24].

Low or medium-viscosity CMC and rice starches with different amylose contents have been blended, and the blends were treated with dry heat [25]. It was found that the pasting properties of the modified starch were markedly changed because of the crosslink between the CMC and starch. Pectin is a polymer with complex structure which is composed of at least 17 different monosaccharides [26]. Pectin is a natural polymer with good emulsifying and gelation property, and it is a new multifunctional natural food additive used in food industry $[27,28]$.

Sweet potato starch has been blended with pectin using dry heat treatment, and it was found that the gelatinization and gel properties of the sweet potato starch were greatly improved [29]. The purpose of this study was to broaden the application of modified potato starch in food and pharmaceutical industries by determining the properties of modified potato starch and pectin blends after dry heating.

\section{EXPERIMENTAL}

\section{Materials and reagents}

Potato starch was purchased from Beijing Minsong Economic And Trade Co. Ltd, China. Pectin was purchased from America Tang Ruisi Food Materials Company. Sodium hydroxide and hydrochloric acid were of analytical grade.

\section{Dry heat treatment of potato starch}

Pectin (1-5\%) was added to $170 \mathrm{~mL}$ of ultrapure water and stirred to dissolve completely. Then, $100 \mathrm{~g}$ of potato starch was added to the pectin solution and the $\mathrm{pH}$ was adjusted to 7.0 using 0.2 $\mathrm{M} \mathrm{HCl}$ or $1 \mathrm{M} \mathrm{NaOH}$. Samples were stirred on a magnetic stirrer for $1 \mathrm{~h}$ at room temperature. The mixtures were then dried in an oven at $40^{\circ} \mathrm{C}$ to a moisture content of less than $10 \%$. The samples were crushed with a pulverizer and passed through a 100 mesh sieve. In addition, the dried mixtures with 1 - $5 \%$ pectin were treated with dry heat at $120^{\circ} \mathrm{C}$ for $3 \mathrm{~h}$. The dried mixtures with 3 $\%$ pectin were subjected to dry heat treatment for various durations ( 1 to $5 \mathrm{~h}$ ) at $120^{\circ} \mathrm{C}$, and also to temperatures varying from 100 to $140^{\circ} \mathrm{C}$ for $3 \mathrm{~h}$. At the same time, raw potato starch was used as control check 1 (ck1). The blends of potato and 3 $\%$ pectin dried mixtures without dry heat treatment were used as control check 2 (ck2).

\section{Pasting analysis}

Rapid Visco-Analyzer (RVA) (RVA-Series 4, Newport Scientific Pty. Ltd., Warriewood, Australia) was used to measure pasting properties of the modified potato starches. Starch sample $(2.0 \mathrm{~g})$ was dissolved in ultrapure water $(25 \mathrm{~mL})$. The test program is shown in Table 1.

Table 1: Test program for RVA

\begin{tabular}{lcc}
\hline $\begin{array}{l}\text { Time } \\
\text { (HH:MM:SS) }\end{array}$ & $\begin{array}{c}\text { Type (Temp } \\
\text { speed) }\end{array}$ & $\begin{array}{c}\text { Viscosity } \\
\left({ }^{\circ} \mathbf{C}\right) \\
\text { or }(\text { RPM })\end{array}$ \\
\hline 0:00:00 & $\begin{array}{c}\text { Temp } \\
\text { 0:00:00 }\end{array}$ & 50 \\
S:00:10 & Speed & 960 \\
0:01:00 & Temp & 160 \\
0:04:42 & Temp & 50 \\
0:07:12 & Temp & 95 \\
0:11:00 & Temp & 55 \\
0:13:00 & End & \\
\hline
\end{tabular}

\section{Thermal characterization}

The thermal properties of the starches were determined using a differential scanning calorimeter (DSC, TA Instruments-Waters LLC, America) equipped with a thermal analysis data station. Steel plates were used to hold samples in the test. Starch sample $(0.1 \mathrm{~g})$ and $0.2 \mathrm{~mL}$ ultrapure water were mixed evenly. Then, the mixed samples $(8-12 \mathrm{mg}$ ) were taken into the steel pan and sealed. The test program was run at a scanning temperature range of $30-100{ }^{\circ} \mathrm{C}$, with a ramp rate $10{ }^{\circ} \mathrm{C} / \mathrm{min}$. The curve peaks were analyzed with TA Universal Analysis Software. 


\section{Textural analysis}

Starch sample $(2.0 \mathrm{~g})$ was dissolved in ultrapure water $(25 \mathrm{~mL})$ and completely gelatinized using the method used for the RVA measurement. The gelatinized starches were then stored in small aluminum canisters at $4{ }^{\circ} \mathrm{C}$ for $24 \mathrm{~h}$ to form gel. The texture of the gels was analyzed using the texture analyzer (SMS, model TA-XT2i Stable Micro System, England) with a $36 \mathrm{~mm}$ probe (P36R). The conditions used in the test program were: pre-test speed of $1 \mathrm{~mm} / \mathrm{sec}$; test speed of $0.5 \mathrm{~mm} / \mathrm{sec}$; post-test speed of $1 \mathrm{~mm} / \mathrm{sec}$; compression ratio of $25 \%$ deformation; and force of $5 \mathrm{~g}$.

\section{Particle size analysis}

The particle size of the samples was analyzed using a laser particle size distribution device (BT$9300 \mathrm{H}$ Laser Particle Size Distribution Meter, Dandong Baxter Instrument Co., Ltd., China), according to the method reported by Wang et al [30]. The potato starch was dispersed into distilled water as described previously [31]. The size was set in the range of $0.1-341 \mu \mathrm{m}$.

\section{SEM analysis}

A Quanta 200 environmental scanning electron microscope (FEl Company, USA) was used to record scanning electron microscopy (SEM) micrographs. The conductive double-sided adhesives with starch samples were evenly distributed on the top and stuck to SEM specimen stubs. The micrographs were received with an accelerating potential of $15 \mathrm{kV}$ under low vacuum, and were used to detect the morphology of starch granules.

\section{Fourier transform-infrared (FTIR) spectro- scopy}

The samples were scanned with FTIR (Nicolet 470; Perkin Elmer Inc., Waltham, MA, USA) to obtain the FTIR spectrum. The scanning spectrum range was $4000 \mathrm{~cm}^{-1}$ to $400 \mathrm{~cm}^{-1}$ at a resolution of $0.44 \mathrm{~cm}^{-1}$. The samples were diluted with $\operatorname{KBr}(1: 100, w / w)$ before scanning, and pure $\mathrm{KBr}$ was acquired as background viscosity beforehand.

\section{X-ray diffractometry}

The $x$-ray diffraction (XRD) analysis of the starches was performed with $\mathrm{X}$-ray diffractometer (PANalytical, X'Pert3 Powder, Netherlands). The micrographs were received at $15 \mathrm{kV}$ acceleration potential in low vacuum. The samples were ground, sieved through 120 mesh screen, and pressed onto plates. The operating conditions were: diffraction angle $(2 \theta)$ of $5-80^{\circ}$; emission slit of $1^{\circ}$; anti-scattering slit of $1^{\circ}$; receiving slit of $0.3 \mathrm{~mm}$; step width of $0.02^{\circ}$; and preset time of $0.1 \mathrm{sec}$.

\section{Statistical analysis}

Data were measured three times and SPSS Statistics 17.0 was used to calculate the mean and standard deviation. Origin8.0 software was used for drawing. Values of $p<0.05$ were considered to be significant.

\section{RESULTS}

\section{Effect of pectin concentration on pasting properties of potato starches}

The RVA parameters for potato starches with different levels of pectin are listed in Table 2. The peak, trough, breakdown, final viscosity and pasting temperature of the starch added $3 \%$ pectin without dry heat treatment (ck2) were lower than those of raw potato starch (ck1). The peak, breakdown viscosity and pasting temperature of potato starch and pectin blends subjected to dry heat treatment were all lower than those of ck1 and ck2. With increase in pectin concentration, the peak and breakdown viscosity of the blends given dry heat treatment were gradually decreased. The final and setback viscosity of the blends subjected to dry heat treatment were higher than those of ck1 and ck2. However, the setback viscosity of the blends with dry heat treatment was gradually increased with increase in pectin concentration. The highest setback viscosity was $1659 \mathrm{cP}$ when pectin concentration was $4 \%$.

\section{Effect of dry heat treatment time on pasting properties of potato starches}

The RVA parameters of the blends of potato starches with $3 \%$ pectin subjected to dry heat for different durations are shown in Table 3 . The RVA parameters of the blends treated with dry heat for different times were lower than those of ck1 and ck2. With increase in dry heat time, peak viscosity was gradually decreased. In addition, the breakdown decreased initially, and then increased, and the lowest breakdown $853 \mathrm{cP}$ was obtained at dry heat treatment time of $4 \mathrm{~h}$. The final viscosity and setback of the blends with different dry heat times were higher those of ck1 and ck2. The highest final viscosity was $4465 \mathrm{cP}$ at dry heat treatment time of $4 \mathrm{~h}$. However, the setback viscosities of the blends subjected to different dry heat treatment times were gradually increased with increase in treatment time. When 
the dry heat treatment duration was $5 \mathrm{~h}$, the setback reached the highest value of(1421 cP.

\section{Effect of dry heat treatment temperature on pasting properties of potato starches}

The RVA parameters for the blends of potato starches with $3 \%$ pectin treated at different dry heat temperatures are shown in Table 4. The peak and breakdown viscosities of the blends treated at different dry heat temperature were lower than those of ck1 and ck2, and gradually decreased with increase in dry heat temperature. The lowest breakdown was $792 \mathrm{cP}$ at a temperature of $140{ }^{\circ} \mathrm{C}$. At the same time, the setback viscosities of the blends treated at different dry heat temperatures were higher than those of ck1 and ck2, and gradually increased with increase in temperature. When the dry heat treatment temperature was $140{ }^{\circ} \mathrm{C}$, the setback viscosity peaked at a value of $1575 \mathrm{cP}$.

Effect of pectin concentration on
thermodynamic properties of potato
starches

The thermodynamic properties of the potato starches with different additions of pectin are shown in Table 5. The peak temperature $(\mathrm{Tp})$ of ck2 $\left(72.17^{\circ} \mathrm{C}\right)$ was higher than that of ck1 (68.37 $\left.{ }^{\circ} \mathrm{C}\right)$. There was no obvious difference between the gelatinization temperature ranges (Tc-To) of ck1 and ck2. However, the gelatinization enthalpy $(\Delta \mathrm{H})$ of ck2 $(2.847 \mathrm{~J} / \mathrm{g}$ was much lower than that of ck1 $(4.659 \mathrm{~J} / \mathrm{g})$. The blends subjected to dry-heating treatment had broader ranges of gelatinization temperatures (Tc-To) than ck1 and ck2. The Tp of the blends with dryheating treatment was lower than those of $\mathrm{ck} 1$ and ck2 when pectin concentration was $2-5 \%$. Dry-heating treatment decreases the onset temperature (To) of the blends, when compared with ck1 and ck2. The $\Delta \mathrm{H}$ values of the potato starches treated with dry-heating at different levels of pectin were higher than those of ck2, but lower than those of ck1. When the pectin concentration was $4 \%$, the starch had broader range of gelatinization temperature (Tc-To, 24.85 $\left.{ }^{\circ} \mathrm{C}\right)$ and higher gelatinization enthalpy $(4.373 \mathrm{~J} / \mathrm{g})$ than that of other groups.

\section{Effect of dry heat time on thermodynamic properties of potato starches}

The thermodynamic properties of the starch and pectin blends at different dry heat treatment times are shown in Table 6. The gelatinization peak temperatures $(T p)$ of the blends treated subjected to different dry heat times were decreased initially, and then increased with increase in dry heat time. The lowest gelatinization peak temperature (Tp) was $64.4^{\circ} \mathrm{C}$ at dry heat time of $3 \mathrm{~h}$. The onset temperatures (To) of the blends treated at different dry heat times were lower than those of $c k 1$ and ck2. In addition, the gelatinization temperature ranges (Tc-To) of blends treated at different dry heat times were all distinctly higher than those of ck1 and ck2. At dry-heat treatment time of $3 \mathrm{~h}$, the To of the blends was $58.06{ }^{\circ} \mathrm{C}$, which was lower than those of other dry heating time groups. Moreover, when the dry heat time was $4 \mathrm{~h}$, the blends had a broader gelatinization temperature range $\left(\mathrm{Tc}-\mathrm{To}, 25.83^{\circ} \mathrm{C}\right)$ and higher gelatinization enthalpy $(3.561 \mathrm{~J} / \mathrm{g})$.

\section{Effect of dry heat temperature on thermodynamic properties of potato starches}

The thermodynamic properties of the starch and pectin blends treated at different dry heat temperatures are shown in Table 7. The peak temperature (Tp) of the blends treated at different dry heat temperatures showed irregular changes with increase in temperature, and the highest peak temperature $\left(\mathrm{Tp}, 72.19^{\circ} \mathrm{C}\right.$ ) was obtained at dry heat treatment at $130{ }^{\circ} \mathrm{C}$. Similarly, the onset temperature (To) of the blends treated at different dry heat temperatures was lower than those of ck1 and ck2. The gelatinization temperature ranges (Tc-To) of the blends treated at different dry heat temperatures were broader than those of ck1 and ck2. The broadest gelatinization temperature range (TcTo, $27.18{ }^{\circ} \mathrm{C}$ ) and the highest gelatinization enthalpy $(\Delta \mathrm{H}, 4.244)$ were obtained at $140^{\circ} \mathrm{C}$.

Table 2: RVA parameters of potato starches with different additions of pectin

\begin{tabular}{|c|c|c|c|c|c|c|}
\hline $\begin{array}{l}\text { Pectin } \\
\text { concentration (\%) }\end{array}$ & Peak (cP) & $\begin{array}{l}\text { Trough } \\
\text { (cP) }\end{array}$ & $\begin{array}{l}\text { Breakdown } \\
\text { (cP) }\end{array}$ & $\begin{array}{c}\text { Final } \\
\text { viscosity }(\mathrm{cP})\end{array}$ & $\begin{array}{l}\text { Setback } \\
\text { (cP) }\end{array}$ & $\begin{array}{l}\text { Pasting temperature } \\
\left({ }^{\circ} \mathrm{C}\right)\end{array}$ \\
\hline ck1 & $5056 \pm 9^{a}$ & $3364 \pm 8^{a}$ & $1692 \pm 9^{\mathrm{a}}$ & $4066 \pm 7^{\mathrm{d}}$ & $702 \pm 16^{\top}$ & $71.95 \pm 0.38^{\mathrm{a}}$ \\
\hline ck2 & $4747 \pm 11^{\mathrm{D}}$ & $3111 \pm 11^{c}$ & $1636 \pm 10^{a}$ & $3954 \pm 12^{a}$ & $843 \pm 8^{e}$ & $68.65 \pm 0.22^{b}$ \\
\hline 1 & $4420 \pm 9^{c}$ & $3138 \pm 12^{\mathrm{b}}$ & $1282 \pm 13^{\mathrm{b}}$ & $4060 \pm 16^{a}$ & $922 \pm 10^{a}$ & $67.05 \pm 0.38^{a}$ \\
\hline 2 & $4392 \pm 8^{c}$ & $3236 \pm 9^{b}$ & $1156 \pm 15^{c}$ & $4132 \pm 12^{c}$ & $896 \pm 14^{a}$ & $67.85 \pm 0.23^{\mathrm{C}}$ \\
\hline 3 & $4203 \pm 12^{c}$ & $3172 \pm 8^{\mathrm{b}}$ & $1031 \pm 11^{\mathrm{a}}$ & $4355 \pm 12^{\mathrm{b}}$ & $1183 \pm 14^{\mathrm{C}}$ & $67.8 \pm 0.19^{\mathrm{C}}$ \\
\hline 4 & $4072 \pm 15^{\mathrm{d}}$ & $3031 \pm 13^{c}$ & $1041 \pm 11^{\mathrm{c}}$ & $4690 \pm 7^{\mathrm{a}}$ & $1659 \pm 11^{a}$ & $67.8 \pm 0.24^{\mathrm{c}}$ \\
\hline 5 & $3821 \pm 9^{d}$ & $2714 \pm 18^{\mathrm{a}}$ & $1107 \pm 7^{c}$ & $4149 \pm 11^{\mathrm{c}}$ & $1435 \pm 11^{\mathrm{b}}$ & $67.85 \pm 0.32^{c}$ \\
\hline
\end{tabular}


Table 3: RVA parameters of the blends with different dry-heating treatment times

\begin{tabular}{|c|c|c|c|c|c|c|}
\hline $\begin{array}{l}\text { Dry-heating } \\
\text { time (h) }\end{array}$ & Peak (cP) & $\begin{array}{l}\text { Trough } \\
\text { (cP) }\end{array}$ & Breakdown (cP) & $\begin{array}{l}\text { Final viscosity } \\
\text { (cP) }\end{array}$ & $\begin{array}{l}\text { Setback } \\
\text { (cP) }\end{array}$ & $\begin{array}{c}\text { Pasting temperature } \\
\left({ }^{\circ} \mathrm{C}\right)\end{array}$ \\
\hline ck1 & $5056 \pm 9^{a}$ & $3364 \pm 18^{a}$ & $1692 \pm 9^{a}$ & $4066 \pm 7^{c}$ & $702 \pm 16^{e}$ & $71.95 \pm 0.38^{\mathrm{a}}$ \\
\hline ck2 & $4747 \pm 11^{\mathrm{b}}$ & $3111 \pm 11^{\mathrm{c}}$ & $1636 \pm 10^{a}$ & $3954 \pm 12^{c}$ & $843 \pm 8^{d}$ & $68.65 \pm 0.22^{b}$ \\
\hline 1 & $4629 \pm 10^{\mathrm{b}}$ & $3246 \pm 10^{b}$ & $1383 \pm 11^{\mathrm{b}}$ & $4049 \pm 9^{c}$ & $803 \pm 12^{d}$ & $67 \pm 0.26^{c}$ \\
\hline 2 & $4354 \pm 11^{\mathrm{C}}$ & $3283 \pm 12^{b}$ & $1071 \pm 6^{\mathrm{c}}$ & $4157 \pm 10^{\mathrm{b}}$ & $874 \pm 10^{\mathrm{d}}$ & $67.8 \pm 0.12^{\mathrm{b}}$ \\
\hline$\overline{3}$ & $4203 \pm 12^{c}$ & $3172 \pm 8^{c}$ & $1031 \pm 11^{c}$ & $4355 \pm 12^{a}$ & $1183 \pm 14^{\mathrm{C}}$ & $67.8 \pm 0.19^{\mathrm{D}}$ \\
\hline 4 & $4103 \pm 15^{\mathrm{a}}$ & $3250 \pm 13^{\mathrm{b}}$ & $853 \pm 16^{a}$ & $4465 \pm 16^{a}$ & $1215 \pm 14^{\mathrm{b}}$ & $67.85 \pm 0.08^{\mathrm{D}}$ \\
\hline 5 & $3867 \pm 16^{\mathrm{e}}$ & $2853 \pm 14^{a}$ & $1014 \pm 10^{c}$ & $4274 \pm 6^{\mathrm{b}}$ & $1421 \pm 13^{a}$ & $67.05 \pm 0.12^{c}$ \\
\hline
\end{tabular}

Table 4: RVA parameters for potato starches at different dry-heating temperatures

\begin{tabular}{|c|c|c|c|c|c|c|}
\hline $\begin{array}{l}\text { Dry-heating } \\
\text { temperature } \\
\left({ }^{\circ} \mathrm{C}\right)\end{array}$ & $\begin{array}{l}\text { Peak } \\
\text { (cP) }\end{array}$ & Trough (cP) & $\begin{array}{c}\text { Breakdown } \\
\text { (cP) }\end{array}$ & $\begin{array}{c}\text { Final } \\
\text { viscosity } \\
\text { (cP) }\end{array}$ & $\begin{array}{l}\text { Setback } \\
\text { (cP) }\end{array}$ & $\begin{array}{c}\text { Pasting } \\
\text { Temperature } \\
\left({ }^{\circ} \mathrm{C}\right)\end{array}$ \\
\hline ck1 & $5056 \pm 9^{a}$ & $3364 \pm 8^{a}$ & $1692 \pm 19^{a}$ & $4066 \pm 17^{C}$ & $702 \pm 16^{\mathrm{d}}$ & $71.95 \pm 0.38^{a}$ \\
\hline ck2 & $4747 \pm 11^{\mathrm{D}}$ & $3111 \pm 11^{\mathrm{D}}$ & $1636 \pm 10^{a}$ & $3954 \pm 12^{a}$ & $843 \pm 8^{c}$ & $68.65 \pm 0.22^{\mathrm{D}}$ \\
\hline 100 & $4522 \pm 16^{\mathrm{C}}$ & $3094 \pm 9^{b}$ & $1428 \pm 17^{\mathrm{b}}$ & $4181 \pm 11^{c}$ & $1087 \pm 9^{b}$ & $67 \pm 0.19^{c}$ \\
\hline 110 & $4418 \pm 14^{c}$ & $3132 \pm 14^{\mathrm{b}}$ & $1286 \pm 13^{c}$ & $4257 \pm 15^{b}$ & $1125 \pm 13^{b}$ & $67.25 \pm 0.31^{c}$ \\
\hline 120 & $4203 \pm 12^{\mathrm{d}}$ & $3172 \pm 8^{b}$ & $1031 \pm 41^{\mathrm{d}}$ & $4355 \pm 12^{b}$ & $1183 \pm 14^{b}$ & $67.8 \pm 0.19^{c}$ \\
\hline 130 & $3872 \pm 8^{\mathrm{e}}$ & $2992 \pm 9^{C}$ & $880 \pm 17^{\mathrm{e}}$ & $4536 \pm 9^{a}$ & $1544 \pm 10^{a}$ & $67.9 \pm 0.14^{c}$ \\
\hline 140 & $3766 \pm 5^{a}$ & $2974 \pm 11^{c}$ & $792 \pm 11^{\dagger}$ & $4549 \pm 15^{a}$ & $1575 \pm 10^{a}$ & $68.8 \pm 0.06^{\mathrm{b}}$ \\
\hline
\end{tabular}

Table 5: Thermal properties of starches containing different concentrations of pectin

\begin{tabular}{lccccc}
\hline $\begin{array}{l}\text { Pectin } \\
\text { concentration (\%) }\end{array}$ & To $\left({ }^{\circ} \mathbf{C}\right)$ & Tp $\left({ }^{\circ} \mathbf{C}\right)$ & Tc $\left({ }^{\circ} \mathbf{C}\right)$ & Tc-To $\left({ }^{\circ} \mathbf{C}\right)$ & $\Delta \mathbf{H}(\mathbf{J} / \mathbf{g})$ \\
\hline ck1 & 62.76 & 68.37 & 83.08 & 20.32 & 4.659 \\
ck2 & 64.76 & 72.17 & 84.78 & 20.02 & 2.847 \\
1 & 60.48 & 69.65 & 84.02 & 23.54 & 2.915 \\
2 & 59.75 & 68.24 & 83.96 & 24.21 & 3.713 \\
3 & 58.06 & 64.4 & 80.89 & 22.83 & 3.395 \\
4 & 58.75 & 66.35 & 83.6 & 24.85 & 4.373 \\
5 & 60.67 & 67.16 & 83.13 & 22.46 & 3.681 \\
\hline
\end{tabular}

Table 6: Thermal properties of starches at dry-heating treatment times

\begin{tabular}{lccccc}
\hline $\begin{array}{l}\text { Dry-heating time } \\
\text { (h) }\end{array}$ & To $\left({ }^{\circ} \mathbf{C}\right)$ & Tp $\left({ }^{\circ} \mathbf{C}\right)$ & Tc $\left({ }^{\circ} \mathbf{C}\right)$ & Tc-To $\left({ }^{\circ} \mathbf{C}\right)$ & $\Delta \mathbf{H}(\mathbf{J} / \mathbf{g})$ \\
\hline ck1 & 62.76 & 68.37 & 83.08 & 20.32 & 4.659 \\
ck2 & 64.76 & 72.17 & 84.78 & 20.02 & 2.847 \\
1 & 61.88 & 68.94 & 83.43 & 21.55 & 2.489 \\
2 & 60.8 & 68.45 & 84.97 & 24.17 & 2.663 \\
3 & 58.06 & 64.4 & 80.89 & 22.83 & 3.395 \\
4 & 58.26 & 66.24 & 84.09 & 25.83 & 3.561 \\
5 & 60.65 & 70.15 & 83.66 & 23.01 & 3.096 \\
\hline
\end{tabular}

Table 7: Thermograms of starches at different dry-heating treatment temperatures

\begin{tabular}{lccccc}
\hline $\begin{array}{l}\text { Dry-heating } \\
\text { temperature }\left({ }^{\circ} \mathbf{C}\right)\end{array}$ & To $\left({ }^{\circ} \mathbf{C}\right)$ & Tp $\left({ }^{\circ} \mathbf{C}\right)$ & Tc $\left({ }^{\circ} \mathbf{C}\right)$ & Tc-To $\left({ }^{\circ} \mathbf{C}\right)$ & $\Delta \mathbf{H}(\mathbf{J} / \mathbf{g})$ \\
\hline ck1 & 62.76 & 68.37 & 83.08 & 20.32 & 4.659 \\
ck2 & 64.76 & 72.17 & 84.78 & 20.02 & 2.847 \\
100 & 59.41 & 66.14 & 80.66 & 21.25 & 3.187 \\
110 & 60.84 & 69.65 & 83.08 & 22.24 & 2.979 \\
120 & 58.06 & 64.4 & 80.89 & 22.83 & 3.395 \\
130 & 61.79 & 72.19 & 84.79 & 23 & 3.141 \\
140 & 57.11 & 63.92 & 84.29 & 27.18 & 4.244 \\
\hline
\end{tabular}




\section{Effect of pectin concentration on gel texture properties of starch gels}

The textural properties of gel blends of potato starches and pectin are shown in Table 8. The hardness, gumminess and chewiness of ck2 were all higher than those of ck1, but the springiness of $\mathrm{ck} 2$ was lower than that of ck1. The hardness, gumminess and chewiness, cohesiveness and resilience of the blends treated with dry heat were higher than those of ck1 and ck2. With increase in pectin concentration, the hardness, gumminess and chewiness increased initially, and thereafter decreased at pectin concentration of $5 \%$. When the pectin concentration was $4 \%$, the highest hardness, gumminess and chewiness were $244.345 \mathrm{~g}, 232.277 \mathrm{~g}$, and $226.15 \mathrm{~g}$, respectively. However, there were no significant differences in springiness, cohesiveness and resilience among all the blends.

\section{Effect of dry heat treatment times on gel texture properties of starch gels}

The textural properties of gels of the blends treated at different dry heat times are shown in Table 9. The hardness, gumminess and chewiness of the blends were gradually increased with increase in dry heat time. When the dry heat treatment time was $5 \mathrm{~h}$, the highest hardness, gumminess and chewiness were obtained $(252.479 \mathrm{~g}, 239.618 \mathrm{~g}$, and $231.106 \mathrm{~g}$, respectively).

\section{Effect of dry heat temperature on gel texture properties of starch gels}

Table 10 shows the textural properties of gels of the blends treated at different dry heat temperatures. There were obvious differences in the hardness, gumminess and chewiness among the blends. Dry heat treatment temperature was $140{ }^{\circ} \mathrm{C}$ resulted in maximum hardness, gumminess and chewiness of modified starch (433.375, 400.157, and 365.963, respectively).

Table 8: Gel texture properties of potato starch containing various concentrations of pectin

\begin{tabular}{|c|c|c|c|c|c|c|}
\hline $\begin{array}{l}\text { Pectin } \\
\text { Concentration (\%) }\end{array}$ & $\begin{array}{l}\text { Hardness } \\
\text { (g) }\end{array}$ & $\begin{array}{c}\text { Gumminess } \\
\text { (g) }\end{array}$ & $\begin{array}{l}\text { Chewiness } \\
\text { (g) }\end{array}$ & Springiness & $\begin{array}{c}\text { Cohesivenes } \\
\text { s }\end{array}$ & Resilience \\
\hline ck1 & $59.50 \pm 9.13^{\mathrm{d}}$ & $51.07 \pm 10.25^{\mathrm{a}}$ & $51.05 \pm 9.74^{\mathrm{e}}$ & $0.99 \pm 0.02^{\mathrm{a}}$ & $0.86 \pm 0.02^{b}$ & $0.70 \pm 0.01^{b}$ \\
\hline ck2 & $139.36 \pm 8.76^{c}$ & $127.72 \pm 9.09^{c}$ & $124.13 \pm 12.35^{\mathrm{a}}$ & $0.97 \pm 0.02^{\mathrm{a}}$ & $0.92 \pm 0.02^{\mathrm{a}}$ & $0.76 \pm 0.02^{\mathrm{a}}$ \\
\hline 1 & $205.55 \pm 9.04^{\mathrm{b}}$ & $188.79 \pm 11.02^{b}$ & $181.38 \pm 9.58^{\mathrm{C}}$ & $0.96 \pm 0.02^{a}$ & $0.92 \pm 0.02^{\mathrm{a}}$ & $0.76 \pm 0.02^{a}$ \\
\hline 2 & $213.50 \pm 10.98^{b}$ & $197.94 \pm 11.87^{\mathrm{b}}$ & $201.18 \pm 10.89^{b}$ & $0.915 \pm 0.02^{\mathrm{a}}$ & $0.94 \pm 0.03^{\mathrm{a}}$ & $0.78 \pm 0.03^{a}$ \\
\hline 3 & $220.64 \pm 11.73^{\mathrm{a}}$ & $208.57 \pm 9.84^{\mathrm{b}}$ & $204.03 \pm 12.88^{\mathrm{b}}$ & $0.98 \pm 0.03^{\mathrm{a}}$ & $0.95 \pm 0.02^{\mathrm{a}}$ & $0.78 \pm 0.02^{\mathrm{a}}$ \\
\hline 4 & $244.35 \pm 11.93^{\mathrm{a}}$ & $232.28 \pm 7.92^{\mathrm{a}}$ & $226.15 \pm 11.90^{\mathrm{a}}$ & $0.974 \pm 0.03^{a}$ & $0.95 \pm 0.03^{\mathrm{a}}$ & $0.79 \pm 0.02^{\mathrm{a}}$ \\
\hline 5 & $205.14 \pm 10.29^{b}$ & $189.85 \pm 8.73^{\mathrm{D}}$ & $172.67 \pm 10.80^{C}$ & $0.91 \pm 0.03^{\mathrm{a}}$ & $0.93 \pm 0.03^{\mathrm{a}}$ & $0.73 \pm 0.02^{a}$ \\
\hline
\end{tabular}

Table 9: Gel texture properties of the blends at different dry-heating treatment times

\begin{tabular}{lcccccc}
\hline $\begin{array}{l}\text { Dry-heating time } \\
(\mathbf{h})\end{array}$ & $\begin{array}{c}\text { Hardness } \\
(\mathbf{g})\end{array}$ & $\begin{array}{c}\text { Gumminess } \\
(\mathbf{g})\end{array}$ & $\begin{array}{c}\text { Chewiness } \\
(\mathbf{g})\end{array}$ & Springiness & Cohesiveness & Resilience \\
\hline ck1 & $59.50 \pm 9.13^{\mathrm{e}}$ & $51.07 \pm 10.25^{\mathrm{e}}$ & $51.05 \pm 9.74^{\mathrm{e}}$ & $0.99 \pm 0.02^{\mathrm{a}}$ & $0.86 \pm 0.02^{\mathrm{b}}$ & $0.70 \pm 0.01^{\mathrm{b}}$ \\
ck2 & $139.36 \pm 8.76^{\mathrm{a}}$ & $127.72 \pm 9.09^{\mathrm{a}}$ & $124.13 \pm 12.35^{\mathrm{a}}$ & $0.97 \pm 0.02^{\mathrm{a}}$ & $0.92 \pm 0.02^{\mathrm{a}}$ & $0.76 \pm 0.02^{\mathrm{a}}$ \\
1 & $187.48 \pm 10.68^{\mathrm{c}}$ & $177.71 \pm 11.835^{\mathrm{c}}$ & $170.60 \pm 8.540^{\mathrm{c}}$ & $0.98 \pm 0.01^{\mathrm{a}}$ & $0.94 \pm 0.013^{\mathrm{a}}$ & $0.792 \pm 0.03^{\mathrm{a}}$ \\
2 & $188.33 \pm 11.63^{\mathrm{c}}$ & $179.25 \pm 12.65^{\mathrm{c}}$ & $174.09 \pm 6.86^{\mathrm{c}}$ & $0.952 \pm 0.02^{\mathrm{b}}$ & $0.96 \pm 0.02^{\mathrm{a}}$ & $0.81 \pm 0.03^{\mathrm{a}}$ \\
3 & $220.64 \pm 11.73^{\mathrm{b}}$ & $208.57 \pm 9.84^{\mathrm{b}}$ & $204.03 \pm 12.88^{\mathrm{b}}$ & $0.98 \pm 0.03^{\mathrm{a}}$ & $0.95 \pm 0.02^{\mathrm{a}}$ & $0.78 \pm 0.02^{\mathrm{a}}$ \\
4 & $229.63 \pm 12.74^{\mathrm{b}}$ & $219.00 \pm 13.82^{\mathrm{b}}$ & $213.22 \pm 7.16^{\mathrm{b}}$ & $0.974 \pm 0.02^{\mathrm{a}}$ & $0.95 \pm 0.02^{\mathrm{a}}$ & $0.798 \pm 0.02^{\mathrm{a}}$ \\
5 & $252.48 \pm 12.53^{\mathrm{a}}$ & $239.62 \pm 16.24^{\mathrm{a}}$ & $231.11 \pm 8.53^{\mathrm{a}}$ & $0.964 \pm 0.03^{\mathrm{b}}$ & $0.95 \pm 0.02^{\mathrm{a}}$ & $0.789 \pm 0.02^{\mathrm{a}}$ \\
\hline
\end{tabular}

Table 10: Gel texture properties of blends at different dry-heating treatment temperatures

\begin{tabular}{|c|c|c|c|c|c|c|}
\hline $\begin{array}{l}\text { Dry-heating } \\
\text { temperature }\left({ }^{\circ} \mathrm{C}\right)\end{array}$ & $\begin{array}{l}\text { Hardness } \\
(\mathrm{g})\end{array}$ & $\begin{array}{c}\text { Gumminess } \\
\text { (g) }\end{array}$ & $\begin{array}{c}\text { Chewiness } \\
\text { (g) }\end{array}$ & Springiness & Cohesiveness & Resilience \\
\hline ck1 & $59.50 \pm 9.13^{\dagger}$ & $51.07 \pm 10.25^{\dagger}$ & $51.05 \pm 9.74^{\dagger}$ & $0.99 \pm 0.02^{\mathrm{a}}$ & $0.86 \pm 0.02^{b}$ & $0.70 \pm 0.01^{\mathrm{a}}$ \\
\hline ck2 & $139.36 \pm 8.76^{\mathrm{e}}$ & $127.72 \pm 9.09^{\mathrm{e}}$ & $124.13 \pm 12.35^{\mathrm{e}}$ & $0.97 \pm 0.02^{\mathrm{a}}$ & $0.92 \pm 0.02^{\mathrm{a}}$ & $0.76 \pm 0.02^{\mathrm{a}}$ \\
\hline 100 & $240.240 \pm 9.65^{c}$ & $224.28 \pm 10.16^{\mathrm{c}}$ & $217.28 \pm 13.98^{c}$ & $0.97 \pm 0.02^{\mathrm{a}}$ & $0.93 \pm 0.03^{\mathrm{a}}$ & $0.76 \pm 0.01^{\mathrm{a}}$ \\
\hline 110 & $209.87 \pm 10.57^{\mathrm{a}}$ & $195.46 \pm 11.73^{\mathrm{a}}$ & $186.83 \pm 13.09^{a}$ & $0.96 \pm 0.02^{\mathrm{a}}$ & $0.93 \pm 0.02^{\mathrm{a}}$ & $0.73 \pm 0.02^{\mathrm{a}}$ \\
\hline 120 & $220.64 \pm 11.73^{\mathrm{a}}$ & $208.57 \pm 9.84^{a}$ & $204.03 \pm 12.88^{c}$ & $0.98 \pm 0.03^{\mathrm{a}}$ & $0.95 \pm 0.02^{\mathrm{a}}$ & $0.78 \pm 0.02^{\mathrm{a}}$ \\
\hline 130 & $305.70 \pm 13.87^{\mathrm{D}}$ & $289.05 \pm 10.34^{\mathrm{D}}$ & $273.70 \pm 11.65^{\mathrm{b}}$ & $0.95 \pm 0.03^{\mathrm{a}}$ & $0.95 \pm 0.02^{\mathrm{a}}$ & $0.79 \pm 0.02^{\mathrm{a}}$ \\
\hline 140 & $433.38 \pm 14.74^{a}$ & $400.16 \pm 12.353^{a}$ & $365.96 \pm 12.07^{a}$ & $0.92 \pm 0.02^{\mathrm{a}}$ & $0.92 \pm 0.01^{\mathrm{a}}$ & $0.78 \pm 0.02^{\mathrm{a}}$ \\
\hline
\end{tabular}




\section{Particle size distribution of starches}

The particle size distributions of the starches with different pectin concentrations, dry heat times and dry heat temperatures are shown in Figure 1. Comparing $\mathrm{ck} 1$ with $\mathrm{ck} 2$, the proportion of medium size particles $(10 \mu \mathrm{m}-30 \mu \mathrm{m})$ in ck1 was larger than that in ck2, but the proportion of large size particles $(>30 \mu \mathrm{m})$ in ck1 was less than that in ck2. As shown in Figure 1a, the medium size particles of modified starches containing 1 or $2 \%$ pectin were less than that of ck1 and ck2, and the large size particles of modified starches containing 1 or $2 \%$ pectin were more than that of ck1 and ck2. However, the proportion of large starch granules in the blends with dry heat treatment was slightly increased after dry heat treatment, when compared with of ck1, except the modified starch with 1 or $2 \%$ pectin. In addition, medium size particles in the blends were increased, and large size particles were decreased, relative to ck2 (Figure $1 \mathrm{~b}$ and $1 \mathrm{c}$ ).
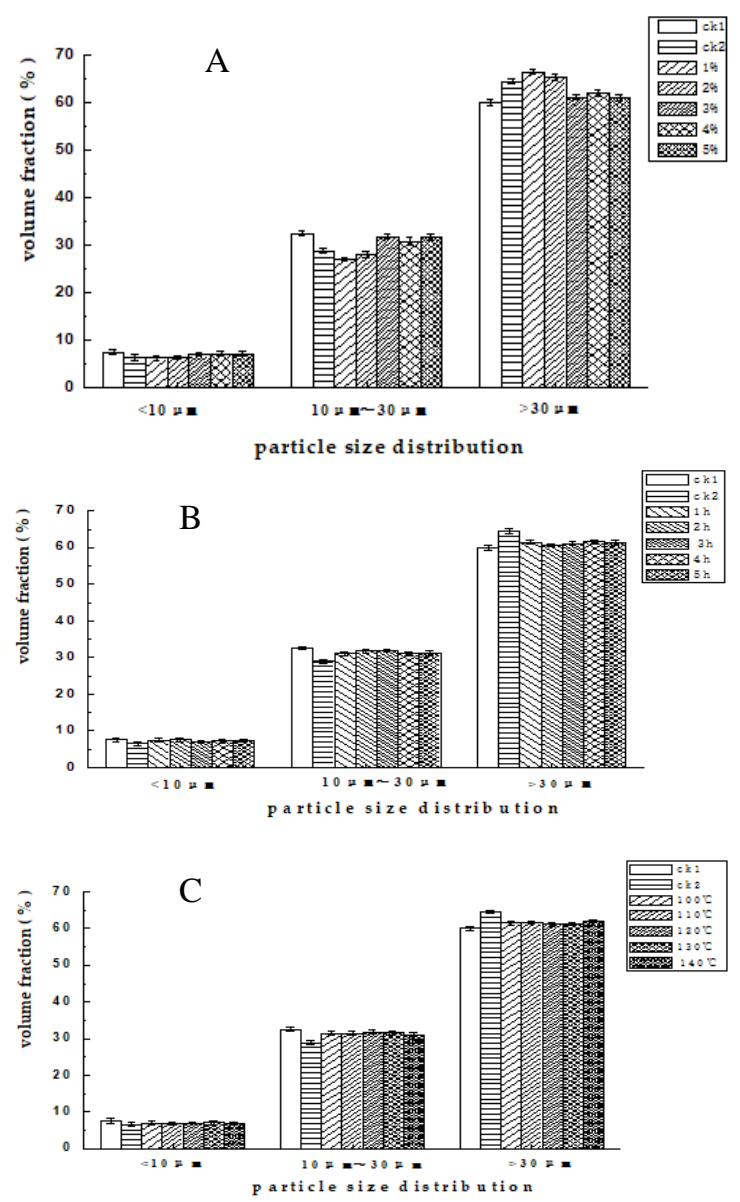

Figure 1: Particle size distribution of starches. (a) Particle size distribution of starches containing different pectin concentrations. (b) Particle size distribution of starches at different dry-heating treatment times. (c) Particle size distribution of starches at different dry-heating treatment temperatures
Particle size distribution of starches at different dry heat treatment temperatures

The particle morphology of starch granules was observed using SEM. The SEM photographs of raw potato starch with or without $3 \%$ pectin, and with or without dry heat treatment $\left(120{ }^{\circ} \mathrm{C}, 3 \mathrm{~h}\right)$ are shown in Figure 2. The raw potato starch had an oval shape with a smooth surface and there was no adhesion between starch granules (Figure 2a). When the raw potato starch and pectin were mixed, the surface of the starch granules were no longer smooth and some pectin was adhered to the surface of starch granules in sheets. The starch granules were still dispersed (Figure 2b). However, when the potato starch with $3 \%$ pectin was treated with dry heat at $120{ }^{\circ} \mathrm{C}$ for $3 \mathrm{~h}$, the starch granules became sticky and clumpy (Figure 2c).

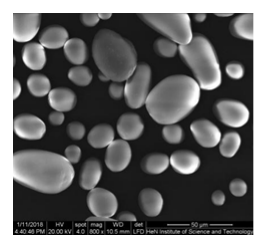

(a)

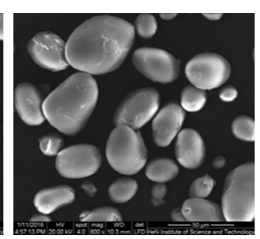

(b)

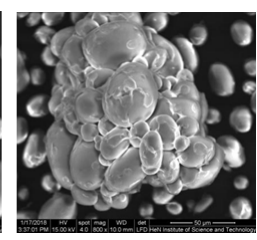

(c)
Figure 2: SEM photographs of the starches (800x). (a) ck1: Raw potato starch; (b) ck2: potato starch with $3 \%$ pectin without dry heat treatment; (c) potato starch with $3 \%$ pectin with dry heat treatment $\left(120^{\circ} \mathrm{C}, 3 \mathrm{~h}\right)$

The FTIR spectra of the samples in the 4000 $400 \mathrm{~cm}^{-1}$ range are shown in Figure 3 . Comparing modified potato starches (Figure 3d) with raw potato starches (Figure 3 a), there was no obvious difference in the infrared spectrum. The peaks at 3305 and $3307 \mathrm{~cm}^{-1}$ could be attributed to $\mathrm{O}-\mathrm{H}$ bond stretching. The peaks at 2929 and $2928 \mathrm{~cm}^{-1}$ were due to $\mathrm{C}-\mathrm{H}$ bond stretching. The peaks at 1645, 1635 and 1634 $\mathrm{cm}^{-1}$ could be attributed to $\mathrm{C}=\mathrm{O}$ bond stretching, while the peaks at 1338 and $1361 \mathrm{~cm}^{-1}$ were attributed to the bent modes of $\mathrm{C}-\mathrm{H}$. The peaks at $1180-953 \mathrm{~cm}^{-1}$ were typical absorption peaks of starch. The peaks at 1149 and $1148 \mathrm{~cm}^{-1}$ were due to $\mathrm{C}-\mathrm{O}$ bond stretching, while the peaks at 993, 992 and $991 \mathrm{~cm}^{-1}$ were related to the formation of hydrogen bonds with the hydroxyl groups on the C-6 carbon atom in the molecule. The peaks at 928 and $925 \mathrm{~cm}^{-1}$ could be attributed to $\mathrm{C}-\mathrm{O}-\mathrm{H}$ bond stretching. The peaks at $860 \mathrm{~cm}^{-1}, 855 \mathrm{~cm}^{-1}$ and $851 \mathrm{~cm}^{-1}$ were attributed to skeleton vibration of $\alpha-1,4$ glucoside bond, and the swaying vibration of $-\mathrm{CH}_{2}$ was near $762 \mathrm{~cm}^{-1}$. The FTIR spectra of pectin is shown in Figure 3c. The peak at $1731 \mathrm{~cm}^{-1}$ was $\mathrm{C}=\mathrm{O}$ characteristic vibration absorption peak of esterified carboxyl functional group $\left(-\mathrm{COOCH}_{3}\right)$, 
which was different from Figure 3a. However, the structures of potato starches (Figure $3 b$ and $3 d$ ) were not affected by the pectin addition or dry heat treatment.

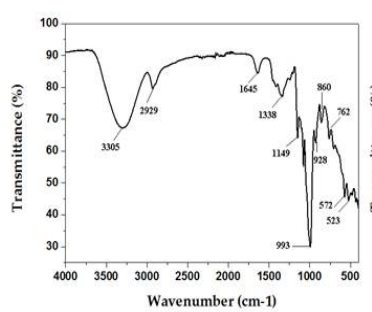

(a)

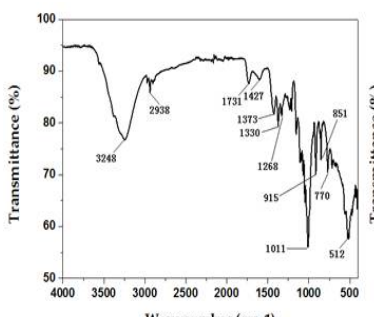

(c)

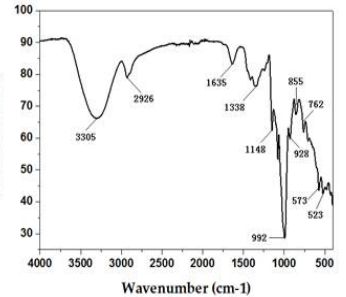

(b)

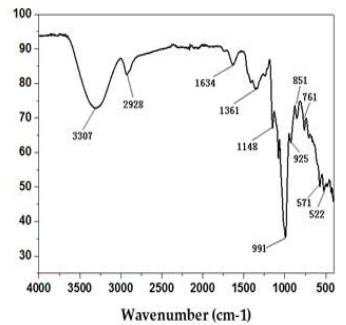

(d)
Figure 3: Infrared spectra. (a) ck1: Raw potato starch;(b) ck2: potato starch with $3 \%$ pectin without dry heat treatment; (c) Pectin; (d) potato starch with $3 \%$ pectin with dry heat treatment $\left(120^{\circ} \mathrm{C}, 3 \mathrm{~h}\right)$

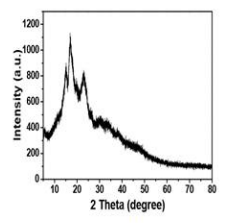

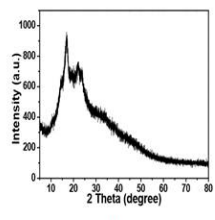

(b)

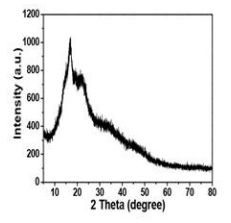

Figure 4: X-ray diffractograms of the starches. (a) ck1: Raw potato starch; (b) ck2: potato starch with $3 \%$ pectin without dry heat treatment; (c) potato starch with $3 \%$ pectin subjected to dry heat treatment (120 ${ }^{\circ} \mathrm{C}, 3 \mathrm{~h}$ )

The x-ray diffractograms of the starches are shown in Figure 4. The strongest diffraction peaks are shown in Figure $4 \mathrm{a}$ (raw potato starch powders) at $2 \theta$ angles of $15.128^{\circ}, 17.103^{\circ}$, and $22.966^{\circ}$, which indicated that the crystal type of the raw potato starch was a characteristic B-type. When $3 \%$ pectin was added to the starch (Figure 4b), the first peak in Figure 1a disappeared and the third peak was weakened. In addition, when the starch with $3 \%$ pectin was subjected to dry heat treatment (Figure 4c), the first peak disappeared, and the third peak was further weakened, when compared to ck2.

\section{DISCUSSION}

Dry heat treatment is a new method for physical modification of starch by combining the advantages of heat treatment with those of the drying process. Compared with raw starch, the properties of the modified starch were improved. This indicates that dry heat treatment is a promising method for producing modified starch. The denaturation of waxy corn starch and potato starch with ionic glue was reported for the first time by Lim et al [32]. The results showed that dry heat treatment with CMC and sodium alginate could increase the gelatinized viscosity of corn starch and decrease the gelatinized viscosity of potato starch, and that dry heat increased the paste viscosity of all the blends of starch and gum tested, except the blends of potato starch and alginate [32].

The physicochemical properties of high amylose, medium amylose, and low amylose rice starches modified by dry-heating treatment with xanthan gum have been investigated [33]. The results showed some interactions between starch and xanthan gum after dry-heating treatment, with the dry-heated xanthan-rice starch samples having higher final viscosity and lower breakdown viscosity. In the present study, the properties of raw potato starch (ck1), potato starch added 3\% pectin without dry heat treatment (ck2), and potato starch added pectin with dry heat treatment were compared. There were slight differences in the breakdown, setback and peak viscosity between ck1 and ck2, while the peak viscosity and breakdown viscosity of the starchpectin blend subjected to dry heat were reduced significantly, and the setback was higher than that of $\mathrm{ck} 1$. When the starch containing $3 \%$ pectin was subjected to dry heat $\left(\mathrm{pH}=9,140^{\circ} \mathrm{C}\right.$, $3 \mathrm{~h}$ ), the peak viscosity was decreased to 1290 cP $(25.51 \%)$. When the starch containing $4 \%$ pectin was treated with dry heat $\left(\mathrm{pH}=9,120{ }^{\circ} \mathrm{C}\right.$, $3 \mathrm{~h}$ ), the setback viscosity was increased $957 \mathrm{cP}$ (136.32\%), and when starch with $3 \%$ pectin was treated with dry heat for $4 \mathrm{~h}\left(\mathrm{pH}=9,120^{\circ} \mathrm{C}\right)$, the breakdown viscosity was reduced $839 \mathrm{cP}$ (49.59\%).

Pectin-containing potato starch subjected to dry heat treatment had broader ranges of gelatinization temperatures (Tc-To) and lower gelatinization enthalpy $(\Delta \mathrm{H})$ than those of $c k 1$ and ck2. At the same time, the hardness, gumminess and chewiness of the potato starch gels containing pectin were improved distinctly when treated with dry heat. Results from SEM showed that after dry heat treatment, starch with pectin showed a cluster shape in microstructure. However, the addition of pectin and dry-heating treatment did not change the starch structure in FTIR spectra. Thus, there was no esterification reaction between the potato starch and pectin. Then, the $\mathrm{x}$-ray diffraction (XRD) of starch 
samples showed that the addition of starch caused the first peak to disappear and blunted the third peak, while dry heat treatment weakened the third peaks again. Changes in starch crystal structure were affected by pectin and dry heat treatment. As a result, the properties of starch were also changed.

\section{CONCLUSION}

The results of this study show that dry heat changes the pasting viscosity, thermodynamic properties, and gel properties of potato starch. The modified potato starch and pectin blends display a cluster shape and disappearance of crystal features. However, FTIR results indicate that no new bonds are formed, and the blends of potato starch and pectin mainly exhibit the infrared spectral characteristics of potato starch. These findings have potential for broadening the application of modified potato starch in food and pharmaceutical industries.

\section{DECLARATIONS}

\section{Acknowledgement}

This work was financially supported by the Program for Innovative Research Talents (in Science and Technology) of the University of Henan Province (no. 16HASTIT015), the Excellent Youth Foundation of the He'nan Scientific Committee (no. 174100510003), and academic talent program of Henan Institute of Science and Technology (no. 205010617006), and Science and Technology Projects in Henan Province (no. 19A550007). The funders had no role in study design, data collection and analysis, decision to publish, or preparation of the manuscript.

\section{Conflict of interest}

No conflict of interest is associated with this work.

\section{Contribution of authors}

We declare that this work was done by the authors named in this article and all liabilities pertaining to claims relating to the content of this article will be borne by the authors.

\section{Open Access}

This is an Open Access article that uses a funding model which does not charge readers or their institutions for access and distributed under the terms of the Creative Commons Attribution License (http://creativecommons.org/licenses/by/ 4.0) and the Budapest Open Access Initiative (http://www.budapestopenaccessinitiative.org/rea d), which permit unrestricted use, distribution, and reproduction in any medium, provided the original work is properly credited.

\section{REFERENCES}

1. Harsselaar JKV, Lorenz J, Senning M, Sonnewald U, Sonnewald S. Genome-wide analysis of starch metabolism genes in potato (solanum tuberosum L.). Bmc Genomics 2017; 18, 37.

2. Sepelevs I, Stepanova V, Galoburda R. Encapsulation of gallic acid with acid-modified low dextrose equivalent potato starch using spray-and freeze-drying techniques. Pol J Food Nutr Sci 2018; 68: 273-280.

3. Pfister B, Zeeman SC. Formation of starch in plant cells. Cell Mol Life Sci 2016; 73: 2781-2807.

4. María M, Ali M, Gemma G, Marie W, Marilyn $R$. Comparative emulsifying properties of octenyl succinic anhydride (osa)-modified starch: granular form vs dissolved state. Plos One 2016; 11: e0160140.

5. Fekete T, Borsa J, Takács E, Wojnárovits L. Synthesis of carboxymethylcellulose/starch superabsorbent hydrogels by gamma-irradiation. Chem Cent J 2017; 11, 46.

6. Alimi BA, Workneh TS. Structural and physicochemical properties of heat moisture treated and citric acid modified acha and iburu starches. Food Hydrocolloid 2018; 81: 449-455.

7. Babu AS, Parimalavalli R, Jagannadham K, Rao JS. Chemical and structural properties of sweet potato starch treated with organic and inorganic acid. J Food Sci Technol 2015; 52: 5745-5753.

8. Lawal OS, Lechner MD, Kulicke WM. Single and multistep carboxymethylation of water yam (dioscorea alata) starch: synthesis and characterization. Int $\mathrm{J}$ Biol Macromol 2008; 42: 429-435.

9. Odeku OA, Picker-Freyer KM. Evaluation of the material and tablet formation properties of modified forms of Dioscorea starches. Drug Dev Ind Pharm 2009; 35 : 1389-1406.

10. Oladebeye AO, Oshodi AA, Amoo IA, Karim $A A$. Functional, thermal and molecular behaviours of ozoneoxidised cocoyam and yam starches. Food Chem 2013; 41: 1416-1423.

11. Fontana JD, Mitchell, DA, Molina OE, Gaitan A, Bonfim TMB, Adelmann J, Grzybowski A, Passos M. Starch depolymerization with diluted phosphoric acid and application of the hydrolysate in Astaxanthin fermentation. Food. Technol. Biotechnol 2008; 46: 305310.

12. Qin Y, Liu C, Jiang S, Cao J, Xiong L, Sun Q. Functional properties of glutinous rice flour by dry-heat treatment. Plos One 2016; 11, e0160371. 
13. Oh IK, Bae IY, Lee HG. Effect of dry-heat treatment on physical property and in vitro starch digestibility of high amylose rice starch. Int J Biol Macromol 2018; 108: 568575.

14. Chung H, Min D, Kim J, Lim S. Effect of minor addition of xanthan on cross-linking of rice starches by dry-heating with phosphate salts. J Appl Polym Sci 2010; 105: 22802286.

15. Baranowska HM, Sikora M, Kowalsk S, Tomasik $P$. Interactions of potato starch with selected polysaccharide hydrocolloids as measured by low-field nmr. Food Hydrocolloid 2008; 22: 336-345.

16. Hussain $R$, Singh A, Vatankhah $H$, Ramaswamy $H S$. Effects of locust bean gum on the structural and rheological properties of resistant corn starch. J Food Sci Technol 2017; 54: 650-658.

17. Kaur A, Shevkani K, Singh N, Sharma P, Kaur S. Effect of guar gum and xanthan gum on pasting and noodlemaking properties of potato, corn and mung bean starches. J Food Sci Technol 2015; 52: 8113-8121.

18. Lim HS, Bemiller JN, Lim Smil. Effect of dry-heating with ionic gums at controlled ph on starch paste viscosity. Cereal Chem 2003; 80: 198-202.

19. Sun $Q$, Si F, Xiong L, Chu L. Effect of dry-heating with ionic gums on physicochemical properties of starch. Food Chem 2013; 136: 1421-1425.

20. Yu Z, Wang YS, Chen HH, Li QQ, Wang Q. The gelatinization and retrogradation properties of wheat starch with the addition of stearic acid and sodium alginate. Food Hydrocolloid 2018; 81: 77-86.

21. Yu Z, Wang YS, Chen HH, Li QQ. Effect of sodium alginate on the gelatinization and retrogradation properties of two tuber starches. Cereal Chem 2018; 95 : 445-455.

22. Riyajan SA. A novel hybrid 2,4-dichlorophenoxy acetate bead from modified cassava starch and sodium alginate with modified natural rubber coating. J Polym Environ 2017; 26: 1950-1961.
23. Song R, Min H, Li B, Zhou B. The effect of three gums on the retrogradation of indica rice starch. Nutrients, 2012; 4: 425-435.

24. Lutfi Z, Nawab A, Alam F, Hasnain A, Haider SZ. Influence of xanthan, guar, CMC and gum acacia on functional properties of water chestnut (trapa bispinosa) starch. Int J Biol Macromol 2017; 103: 220-225.

25. Li Y, Shoemaker CF, Ma J, Shen X, Zhong F. Paste viscosity of rice starches of different amylose content and carboxymethylcellulose formed by dry-heating and the physical properties of their films. Food Chem 2008; 109: 616-623.

26. Ridley BL, O'Neill MA, Mohnen D. Pectins: structure, biosynthesis, and oligogalacturonide-related signaling. Phytochemistry 2001; 57: 929-967.

27. Kaya M, Sousa AG, Crépeau MJ, Sørensen SO, Ralet MC. Characterization of citrus pectin samples extracted under different conditions: influence of acid type and $\mathrm{pH}$ of extraction. Ann Bot 2014; 114: 1319-1326.

28. Watts $P$, Smith A. Pecsys: in situ gelling system for optimised nasal drug delivery. Expert Opin Drug Del 2009; 6: 543-552.

29. Chen M, Guo Y, Li F, Zeng J, Li G. Effect of dry-heating with pectin on gelatinization properties of sweet potato starch. Trop J Pharm Res 2017; 16: 1465-1472.

30. Wang S, Yu J, Yu J, Liu H. Granule structure of c-type chinese yam (dioscorea opposita thunb var. zhongbowen) starch by acid hydrolysis. Food Hydrocolloid 2008; 22: 538-542.

31. Sun JL, Li XH, Zeng J, Liu BG, Li GL. Characterization of dextrin prepared by common neutral and thermostable a-amylases. J Food Process Pres 2010; 34: 621-631.

32. Lim ST, Han JA, Lim HS, Bemiller JN. Modification of starch by dry-heating with ionic gums. Cereal Chem 2002; 79: 601-606.

33. Su J, Chotineeranat $S$, Laoka B, Chatakanonda $P$, Vanichsriratana W, Sriroth K, Piyachomkwan K. Effect of Dry Heat Treatment With Xanthan Gum on Physicochemical Properties of Different Amylose Rice Starches. Starch - Starke 2018; 70: 3-4. 